\title{
Opiliofauna (Arachnida, Opiliones) of the Seasonal Semidecidual Forest of the State of Minas Gerais, Brazil
}

\author{
Adriele Garcia Costa ${ }^{1 *}$ \\ Ludson Neves de Ázara ${ }^{2}$ \\ Mateus Aparecido Clemente ${ }^{3}$ \\ Marcos Magalhães de Souza ${ }^{1}$ \\ ${ }^{1}$ Instituto Federal de Educação, Ciência e Tecnologia do Sul de Minas Gerais \\ Câmpus Inconfidentes, CEP 37.576-000, Inconfidentes - MG, Brazil \\ ${ }^{2}$ Laboratório de Aracnologia, Museu Nacional da Universidade Federal do Rio de Janeiro \\ Rio de Janeiro - RJ, Brazil \\ ${ }^{3}$ Universidade Estadual Paulista "Júlio de Mesquita Filho”, Instituto de Biociências \\ Departamento de Zoologia, Rio Claro - SP, Brazil \\ * Autor para correspondência \\ costaadriele50@gmail.com
}

Submetido em 01/03/2020

Aceito para publicação em 29/05/2020

\section{Resumo}

Opiliofauna (Arachnida, Opiliones) de Floresta Estacional Semidecidual do Estado de Minas Gerais, Brasil. Existem poucos estudos de inventários de opiliões (Arachnida) em muitos ecossistemas e estados brasileiros. Nesse sentido, o objetivo do presente estudo foi inventariar a fauna de opiliões em Floresta Estacional Semidecidual no sul de Minas Gerais. O estudo foi conduzido em 14 municípios no sul do estado de Minas Gerais, em fragmentos de floresta estacional semidecidual, no período de março de 2017 a abril de 2019. Foram registradas 34 morfoespécies, incluindo quatro morfoespécies inéditas para a ciência, Tricommatinae sp.1, Anoplogynus sp.1 e sp.2 e Liogonyleptoides sp.1. A similaridade da fauna de Opiliones é baixa entre os estudos comparados, o que reflete em taxas elevadas de endemismo, como já discutido em outros trabalhos. A área estudada é relevante para a fauna de Opiliones no estado de Minas Gerais, o que justifica na criação de unidades de conservação, a fim de garantir proteção desse patrimônio natural.

Palavras-chave: Anoplogynus; Liogonyleptoides; Mata Atlântica; Tricommatinae

\section{Abstract}

There are few studies of opiliones (Arachnida) catalogs in many ecosystems and Brazilian states. In this regard, the aim of this study was to catalog the harvestmen fauna in a Seasonal Semidecidual Forest in the south of Minas Gerais. The study was conducted in 14 municipalities in the south of the State of Minas Gerais in fragments of a Seasonal Semidecidual Forest from March/2017 to April/2019. 34 morphospecies were registered, including four unknown morphospecies to science, Tricommatinae sp.1, Anoplogynus sp.1 and sp.2, and Liogonyleptoides sp.w1. Similarities in the Opiliones fauna are low within the comparative studies, which reflect on the high rates of endemism, as has been discussed in other studies. The area is relevant to the Opiliones fauna in the state of Minas Gerais, which justifies the creation of conservation units in order to ensure the protection of this natural heritage.

Key words: Anoplogynus; Atlantic Forest; Liogonyleptoides; Tricommatinae 


\section{Introduction}

Due to forest fires, logging, other human activities (LAURANCE; COCHRANE, 2001; ALENCAR et al., 2004; LAURANCE, 2004), increasing agricultural expansion has altered the tropical ecosystems (LAMBIN et al., 2003), causing not only the loss and fragmentation of the forest but also the modification in structure and quality of the habitat, which justifies the study of catalogs and species distribution in tropical rainforests, especially taxons with ecological relevance, but which are still less studied when compared to other groups (MATHIEU et al., 2005; REGO et al., 2007) such as the Opiliones order.

Opiliones comprise the third most diversified order of the Arachnida class (ZHANG, 2013), with 6,653 described species (KURY, 2017). The order is divided into four suborders: Cyphophthalmi, Dyspnoi, Eupnoi and Laniatores (MACHADO et al., 2007).

In the ecosystem, Opiliones play an important role in the process of organic matter decay, since they speed up the cycling of nutrients (MOORE et al., 1991). In addition, with their high rate of endemism, they are an excellent taxon for biogeographic and ecological studies (PINTO-DA-ROCHA et al., 2005; DASILVA et al., 2015).

The greatest abundance of Opiliones in the world can be found Brazil, with 1,008 described species (KURY, 2002 onwards), of which about 600 are unique to the Atlantic Rainforest, the most sampled biome for harvestmen in Brazil (BRAGAGNOLO; PINTODA-ROCHA, 2009), and where the greatest diversity of these arachnids are found (PINTO-DA-ROCHA, 1999; BRAGAGNOLO et al., 2007; NOGUEIRA et al., 2019a). Their sensitivity to changes in habitat, and their vulnerability to water loss (SANTOS, 2007) can explain the greater diversity in the rainforest and their nocturnal behavior (PINTO-DA-ROCHA et al., 2005).

The Atlantic Rainforest comprises a group of forest formations and associated ecosystems that include Dense Ombrophilous Forests, Mixed Ombrophilous Forests, Open Ombrophilous Forests, Seasonal Semidecidual Forests, Seasonal Decidual Forests, Sandbanks, Mangroves, and Highland Fields (OLIVEIRA-FILHO, 2006).
There are few cataloging and distribution works on opiliofauna in the state of Minas Gerais (SOARES, 1970; SOARES; SOARES, 1970; ÁZARA et al., 2016; FERREIRA et al., 2019). The first work was carried out at the Parque Nacional do Itatiaia (Itatiaia National Park), which holds rupestrian and altitude field formations, as well as Ombrophilous forests, spanning both the states of Minas Gerais and Rio de Janeiro. The second was carried out in the municipality of Poços de Caldas, in the area of a Seasonal Semidecidual Forest; the third work registered harvestmen species associated to 111 artificial hollowed underground areas in 13 municipalities, Alagoa, Ataléia, Caeté, Caraí, Mariana, Mateus Leme, Medina, Nova Lima, Novo Oriente de Minas, Ouro Preto, Padre Paraíso, São José da Safira and Vazante, in areas influenced by the Atlantic Rainforest biome and others by the Brazilian Savanna; finally, the fourth was carried out at the Parque Estadual Serra do Papagaio Serra do Papagaio State Park, in the south of the state in ecoregions of Highland Fields and of Mixed Forests of the Atlantic Rainforest biome.

The state of Minas Gerais holds different biomes with several phytophysiognomies, such as the ombrophilous forest, the semidecidual, the decidual, the mixed, and the altitude fields, all under the dominance of the Atlantic Rainforest, Brazilian Savanna, Caatinga, and Rupestrian Fields (OLIVEIRA-FILHO, 2006).

Therefore, different ecosystems and regions of the state, including those of the Atlantic Forest domain are subsampled for the opiliofauna, such as the areas of the Seasonal Semidecidual Montane Forest in the south of the state. In relation to the latter, the aim of this study was to carry out a survey on Opiliones fauna in the Seasonal Semidecidual Forest of the south of Minas Gerais.

\section{Material and Methods}

The study was conducted in 14 municipalities in the south of the state of Minas Gerais (Table 1; Figure 1), in a region where the Seasonal Semidecidual Montane Forest vegetation is predominant, as well as the phytophysiognomy of Atlantic Rainforest dominance (OLIVEIRA-FILHO, 2006). Sample collections were carried out from March/2017 to April/2019. The sampled 
areas show a variable degree of conservation and of ecological succession. All of them suffer distinctive strain from anthropic agents, such as cattle breeding, monoculture, and tourism, and they comprise forest fragments of varying size.
There were 71 sampling days, ten of which had sample collection during the daytime, starting at 8 a.m. and finishing at $10 \mathrm{a} . \mathrm{m}$., and $61 \mathrm{had}$ sample collection at nighttime, starting at $6 \mathrm{p} . \mathrm{m}$. and finishing at $8 \mathrm{p} . \mathrm{m}$. There were 142 hours of sampling effort. Sample collections

FIGURE 1: Municipalities where the sampling of opiliones (Arachnida) were performed in the south of Minas Gerais and Southeastern Brazil.

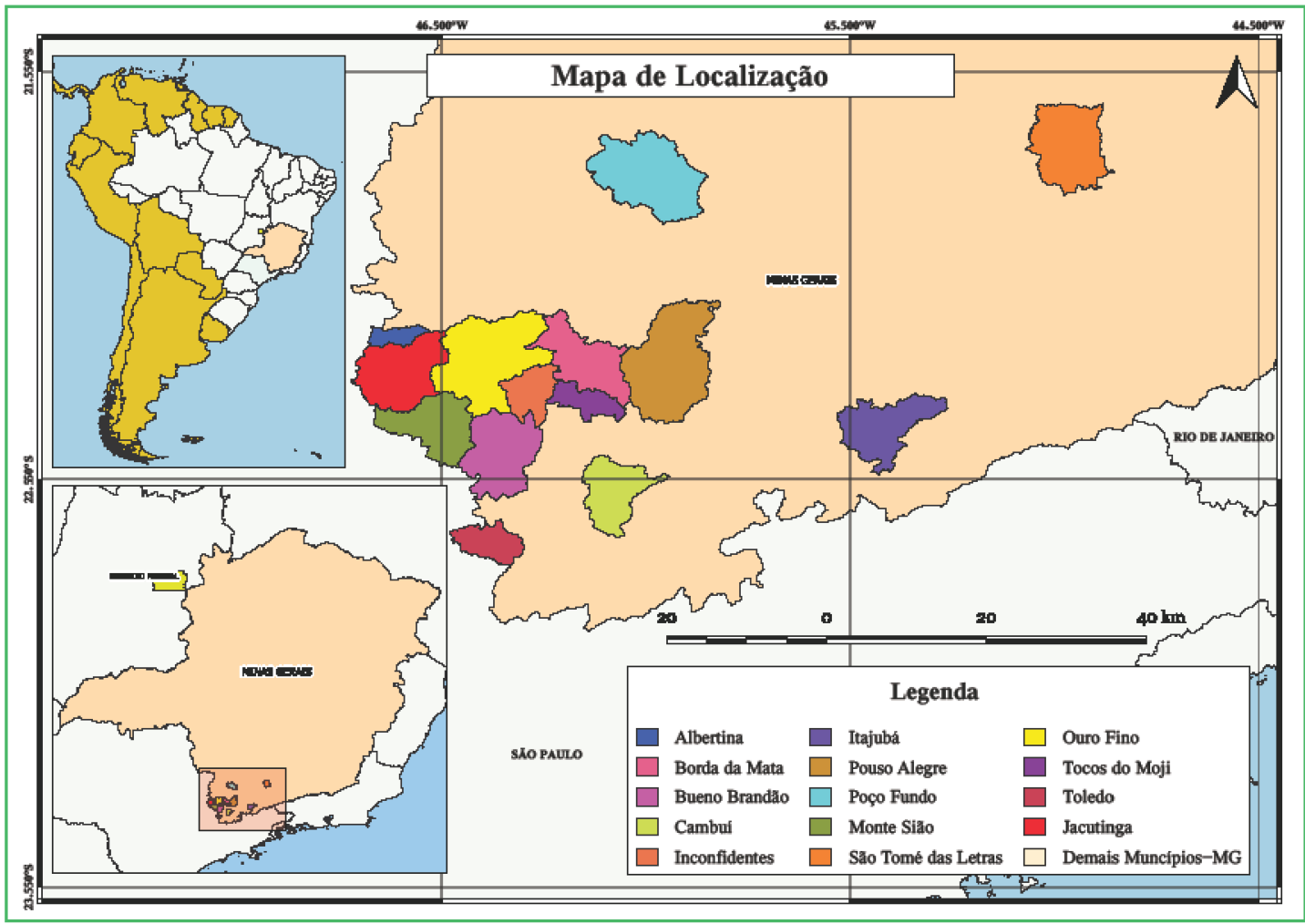

TABLE 1: Number of sampling days of opiliofauna in fragments of Seasonal Semidecidual Forest in municipalities in the south of the state of Minas Gerais, Brazil.

\begin{tabular}{cccc}
\hline Municipality & Geographic Coordinates & Altitude & No. of samples \\
\hline Albertina & $22^{\circ} 12^{\prime} 14^{\prime \prime} \mathrm{S}, 46^{\circ} 36^{\prime} 66^{\prime \prime} \mathrm{E}$ & $1021 \mathrm{~m}$ & 2 \\
Borda da Mata & $22^{\circ} 16^{\prime} 97^{\prime \prime} \mathrm{S}, 46^{\circ} 9^{\prime} 65^{\prime \prime} \mathrm{E}$ & $867 \mathrm{~m}$ & 1 \\
Bueno Brandão & $22^{\circ} 26^{\prime} 73^{\prime \prime} \mathrm{S}, 46^{\circ} 20^{\prime} 47^{\prime \prime} \mathrm{E}$ & $1174 \mathrm{~m}$ & 11 \\
Cambuí & $22^{\circ} 36^{\prime} 77^{\prime \prime} \mathrm{S}, 46^{\circ} 3^{\prime} 74^{\prime \prime} \mathrm{E}$ & $890 \mathrm{~m}$ & 1 \\
Inconfidentes & $22^{\circ} 18^{\prime} 62^{\prime \prime} \mathrm{S}, 46^{\circ} 19^{\prime} 73^{\prime \prime} \mathrm{E}$ & $901 \mathrm{~m}$ & 20 \\
Itajubá & $22^{\circ} 25^{\prime} 38^{\prime \prime} \mathrm{S}, 45^{\circ} 27^{\prime} 94^{\prime \prime} \mathrm{E}$ & $873 \mathrm{~m}$ & 2 \\
Jacutinga & $22^{\circ} 16^{\prime} 62^{\prime \prime} \mathrm{S}, 46^{\circ} 36^{\prime} 13^{\prime \prime} \mathrm{E}$ & $839 \mathrm{~m}$ & 1 \\
Monte Sião & $22^{\circ} 24^{\prime} 65^{\prime \prime} \mathrm{S}, 46^{\circ} 29^{\prime} 18^{\prime \prime} \mathrm{E}$ & $855 \mathrm{~m}$ & 3 \\
Ouro Fino & $22^{\circ} 16^{\prime} 73^{\prime \prime} \mathrm{S}, 46^{\circ} 22^{\prime} 37^{\prime \prime} \mathrm{E}$ & $882 \mathrm{~m}$ & 20 \\
Poço Fundo & $21^{\circ} 46^{\prime} 38^{\prime \prime} \mathrm{S}, 45^{\circ} 58^{\prime} 18^{\prime \prime} \mathrm{E}$ & $829 \mathrm{~m}$ & 1 \\
Pouso Alegre & $22^{\circ} 14^{\prime} 93^{\prime \prime} \mathrm{S}, 45^{\circ} 56^{\prime} 37^{\prime \prime} \mathrm{E}$ & $878 \mathrm{~m}$ & 5 \\
São Thomé das Letras & $21^{\circ} 43^{\prime} 65^{\prime \prime} \mathrm{S}, 44^{\circ} 58^{\prime} 73^{\prime \prime} \mathrm{E}$ & $1247 \mathrm{~m}$ & 1 \\
Tocos Do Moji & $22^{\circ} 22^{\prime} 54^{\prime \prime} \mathrm{S}, 46^{\circ} 5^{\prime} 44^{\prime \prime} \mathrm{E}$ & $1042 \mathrm{~m}$ & 2 \\
Toledo & $22^{\circ} 44^{\prime} 28^{\prime \prime} \mathrm{S}, 46^{\circ} 22^{\prime} 42^{\prime \prime} \mathrm{E}$ & $1099 \mathrm{~m}$ & 1 \\
\hline
\end{tabular}


were centered in the municipalities of Bueno Brandão, Inconfidentes and Ouro Fino due to the convenience in logistics.

The sampling method used was the active search, which consisted in walking along pre-existing paths in different forest fragments without transects demarcation or specific areas. Search prioritized the surveying of microhabitats such as leaf litter ("serapilheira"), gullies, decaying tree trunks, tree barks, under rocks and bromeliads, with the effort of three researchers per sampling.

Opiliones were captured manually with the help of forceps and placed in jars containing alcohol. In order to identify the specimens, the specialist Doc. Ricardo Pinto da Rocha (Zoology Museum of Universidade de São Paulo - USP) was consulted. The specimens were deposited in the Arachnids and Myriapods Collection of the Arachnology Laboratory at the UFRJ National Museum and in the Collection of the Zoology Laboratory of the Instituto Federal de Educação, Ciência e Tecnologia do Sul de Minas Gerais, Câmpus Inconfidentes.

The following formula was used to calculate the constancy: $C=(p \times 100) / N$, where $p=$ number of sample collections containing the studied species and $\mathrm{N}=$ total number of sample collections carried out. The species were then grouped, according to Silveira Neto et al. (1976) in the categories: "constant", for the species present in more than $50 \%$ of the sample collections; "accessory", for those between 25 and 50\%; and "accidental" for those present in less than $25 \%$ of the sample collections.

The species dominance was defined according to the categories established by Friebe (1983), from the relative abundance, being "eudominant" when the species presents $10 \%$ of its individuals in the sample; "dominant", > 5-10\%; "subdominant", > 2-5\%; "recessive" $=1-2 \%$ and "rare", $<1 \%$.

Species estimators (Jackknife 1) were used to evaluate the efficiency of the sample collection, with the use of Software R (R DEVELOPMENT CORE TEAM, 2017), with 1,000 repeated samplings.
In order to evaluate the similarity of the Opiliones fauna sampled in this study, works carried out in the states of São Paulo (RESENDE et al., 2012) and of Rio de Janeiro (BRAGAGNOLO; PINTO-DA-ROCHA, 2003), with a phytophysiognomy of Atlantic Rainforest dominance biome, and of the state of Minas Gerais (SOARES, 1970; ÁZARA et al., 2016; FERREIRA et al., 2019) were used. Only the material identified up to species were used in the analyses, for all the comparative studies and this one. The morphospecies identified up to genera, subfamilies, and families were not considered. A binary matrix was used to analyze the grouping with data from the presence-absence of species in each region. Using the similarity matrix obtained by the community of the Jaccard coefficient (SJ), a dendrogram was built with the UPGMA grouping method. All data was processed in software PAST 2.1 (HAMMER et al., 2001) and FITOPAC 2.1 (SHEPHERD, 2010).

\section{Results}

1,198 individuals belonging to 34 morphospecies distributed in 14 genera, nine subfamilies, three families and two suborders were sampled (Table 2).

The most abundant species was Mischonyx cuspidatus with 669 registered individuals, followed by Discocyrtanus pertenuis with 180 and by Liogonyleptoides sp.1 with 74 specimens.

It is important to note that the taxons that are not identified to the specific level of revised Gonyleptidae subfamilies comprise females, which are morphologically homegeneous and, in general, do not present diagnostic features for specific identification.

Four morphospecies that comprise non-described species to science were sampled (Figure 2): Anoplogynus sp.1 and sp.2 (Municipality: Albertina), Liogonyleptoides sp.1 (Inconfidentes) and Tricommatinae sp.1 (Bueno Brandão). The species estimator Jackknife 1 showed that the Opiliones fauna in the studied region can reach up to 42 species (Figure 3). 
TABLE 2: Suborder, families, subfamilies and Opiliones morphospecies (arachnida) registered in a Seasonal Semidecidual Forest in the south of the state of Minas Gerais, Brazil. *non-described species. $\mathrm{N}=$ abundance.

\begin{tabular}{|c|c|c|c|c|}
\hline Suborder & Family & Subfamily & Species/morphotype & $\mathrm{N}$ \\
\hline Eupnoi & Sclerosomatidae & Gagrellinae & Gagrellinae gen. sp.1 & 4 \\
\hline Eupnoi & Sclerosomatidae & Gagrellinae & Gagrellinae gen.sp.2 & 14 \\
\hline Eupnoi & Sclerosomatidae & Gagrellinae & Gagrellinae gen.sp.3 & 1 \\
\hline Eupnoi & Sclerosomatidae & Gagrellinae & Gagrellinae gen.sp.4 & 1 \\
\hline Laniatores & Cosmetidae & Discosomaticinae & Gryne sp.1 & 3 \\
\hline Laniatores & Gonyleptidae & Bourguyiinae & Asarcus sp.1 & 1 \\
\hline Laniatores & Gonyleptidae & Goniosomatinae & Acutisoma longipes Roewer, 1913 & 20 \\
\hline Laniatores & Gonyleptidae & Goniosomatinae & Goniosomatinae gen. sp. 1 & 6 \\
\hline Laniatores & Gonyleptidae & $?$ & Gonyleptidae gen. sp.1 & 10 \\
\hline Laniatores & Gonyleptidae & Gonyleptinae & Acanthogonyleptes fulvigranulatus (Mello-Leitão, 1922) & 37 \\
\hline Laniatores & Gonyleptidae & Gonyleptinae & Acanthogonyleptes sp. 1 & 3 \\
\hline Laniatores & Gonyleptidae & Gonyleptinae & Currala sp.1 & 8 \\
\hline Laniatores & Gonyleptidae & Gonyleptinae & Gonyleptes atrus Mello-Leitão, 1923 & 12 \\
\hline Laniatores & Gonyleptidae & Gonyleptinae & Gonyleptes sp. 1 & 10 \\
\hline Laniatores & Gonyleptidae & Gonyleptinae & Liogonyleptoides sp. $1 *$ & 74 \\
\hline Laniatores & Gonyleptidae & Gonyleptinae & Longiperna sp.1 & 23 \\
\hline Laniatores & Gonyleptidae & Gonyleptinae & Longiperna trembao Pinto-da-Rocha \& Bragagnolo, 2010 & 2 \\
\hline Laniatores & Gonyleptidae & Gonyleptinae & Mischonyx cuspidatus (Roewer,1913) & 669 \\
\hline Laniatores & Gonyleptidae & Mitobatinae & Discocyrtoides nigricans (Mello-Leitão, 1922) & 2 \\
\hline Laniatores & Gonyleptidae & Mitobatinae & Encheiridium montanum (Mello-Leitão, 1941) & 3 \\
\hline Laniatores & Gonyleptidae & Mitobatinae & Mitobatinae gen. sp.1 & 1 \\
\hline Laniatores & Gonyleptidae & Pachylinae & Anoplogynus nasutus Piza, 1938 & 3 \\
\hline Laniatores & Gonyleptidae & Pachylinae & Anoplogynus sp. $1 *$ & 2 \\
\hline Laniatores & Gonyleptidae & Pachylinae & Anoplogynus sp.2* & 2 \\
\hline Laniatores & Gonyleptidae & Pachylinae & Discocyrtus bos Roewer, 1929 & 9 \\
\hline Laniatores & Gonyleptidae & Pachylinae & Discocyrtus confusus Kury, 2011 & 13 \\
\hline Laniatores & Gonyleptidae & Pachylinae & Discocyrtus invalidus Piza, 1938 & 50 \\
\hline Laniatores & Gonyleptidae & Pachylinae & Discocyrtus flavigranulatus B. Soares, 1944 & 2 \\
\hline Laniatores & Gonyleptidae & Roeweriinae & Discocyrtanus pertenuis (Mello-Leitão, 1935) & 180 \\
\hline Laniatores & Gonyleptidae & Pachylinae & Discocyrtus sp. 1 & 4 \\
\hline Laniatores & Gonyleptidae & Pachylinae & Discocyrtus latus Mello-Leitão, 1935 & 4 \\
\hline Laniatores & Gonyleptidae_ & Pachylinae & Hypophyllonomus sp. 1 & 3 \\
\hline Laniatores & Gonyleptidae & Pachylinae & Pachylinae gen. sp.1 & 21 \\
\hline Laniatores & Gonyleptidae & Tricommatinae & Tricommatinae gen. sp. $1^{*}$ & 1 \\
\hline
\end{tabular}


FIGURE 2: Unheard-of species to science, registered in a Seasonal Semidecidual Forest in the south of the state of Minas Gerais, Brazil. A: Anoplogynus sp.1, B: Anoplogynus sp.2, C: Liogonyleptoides sp.1 and D: Tricommatinae sp.1.
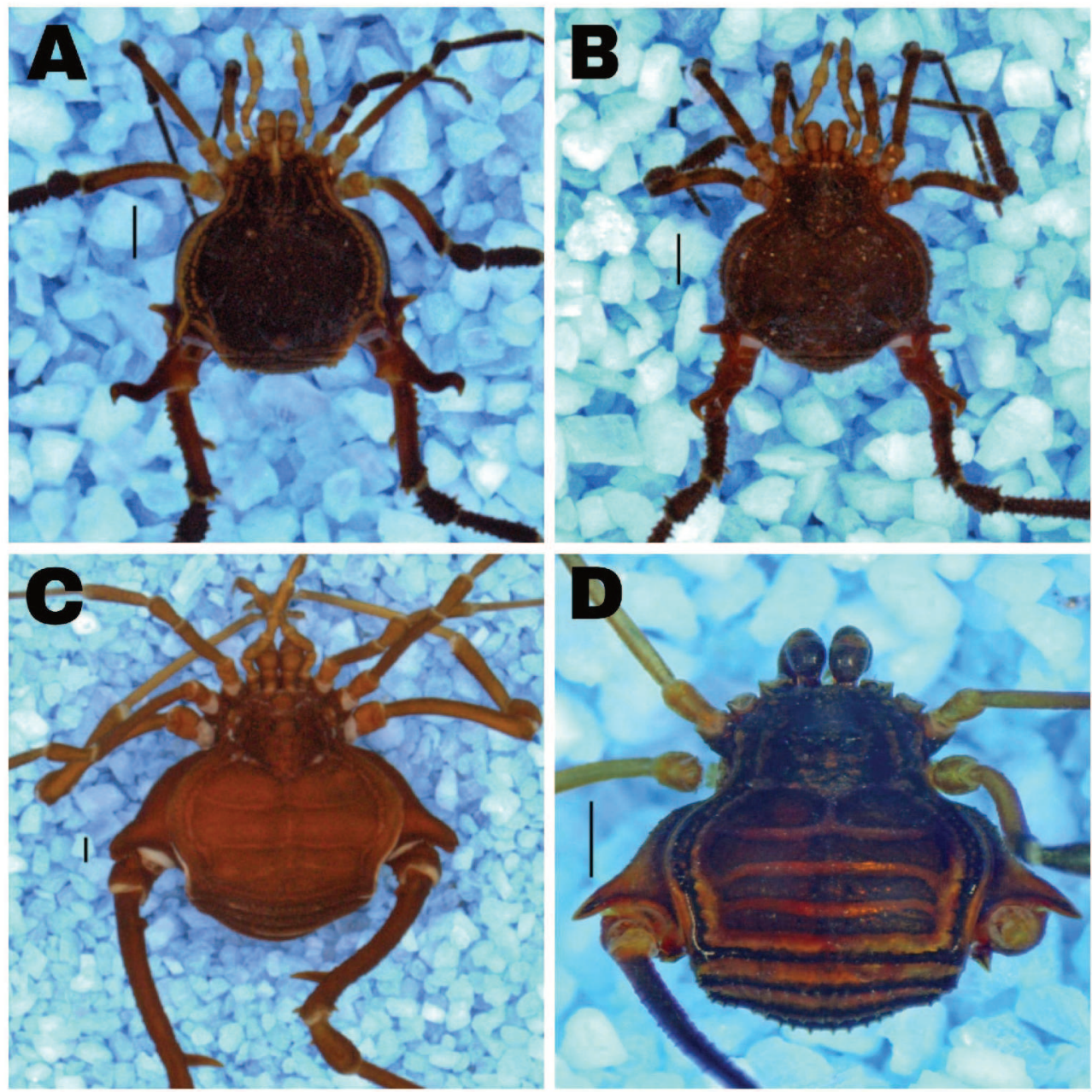

FIGURE 3: Rarefaction curve and abundance estimation (Jackknife 1) of opiliones registered in a Seasonal Semidecidual Forest in the south of the state of Minas Gerais, Brazil. The central line in red represents the number of collected spp.; the blue lines refer to the estimated number of spp. (Jack 1).

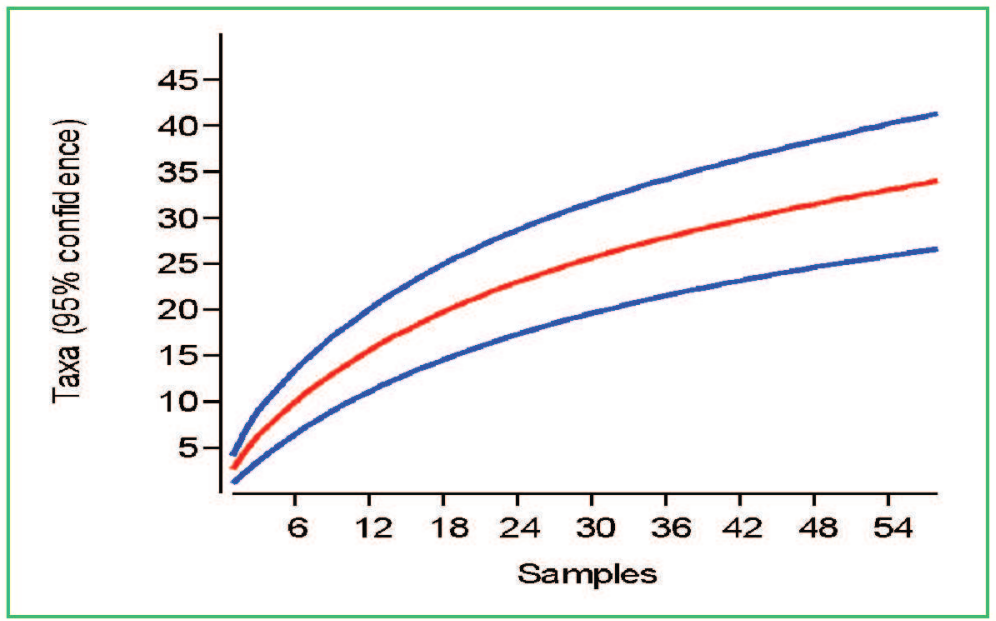


A grouping of this study survey is observed in a low faunal similarity (less than 0.5), which also occurred survey by Ferreira et al. (2019). However, the latter have in the other analyzed studies (Table 3).

TABLE 3: Similarity matrix of the Opiliones fauna (Aracnhida) from studies conducted in southeastern Brazil.

\begin{tabular}{ccccccc}
\hline & $\begin{array}{c}\text { Bragagnolo } \\
\text { and Pinto-da- } \\
\text { Rocha (2003) }\end{array}$ & $\begin{array}{c}\text { Resende et al. } \\
\text { (2012) }\end{array}$ & $\begin{array}{c}\text { Ferreira et al. } \\
\mathbf{( 2 0 1 9 )}\end{array}$ & $\begin{array}{c}\text { Soares } \\
\text { (1970) }\end{array}$ & $\begin{array}{c}\text { Ázara et al. } \\
\text { (2016) }\end{array}$ & Present study \\
\hline $\begin{array}{c}\text { Bragagnolo and Pinto- } \\
\text { da-Rocha (2003) }\end{array}$ & 1 & 0.018867925 & 0 & 0 & 0 & 0 \\
Resende et al. (2012) & 0.018867925 & 1 & 0.028571429 & 0.027777778 & 0 & 0,075 \\
Ferreira et al. (2019) & 0 & 0.028571429 & 1 & 0.0625 & 0.11764706 & 0.21052632 \\
Soares (1970) & 0 & 0.027777778 & 0.0625 & 1 & 0 & 0.14285714 \\
Ázara et al. (2016) & 0 & 0 & 0.11764706 & 0 & 1 & 0,04 \\
Present study & 0 & 0.075 & 0.21052632 & 0.14285714 & 0.04 & 1 \\
\hline
\end{tabular}

The species classified as subdominant were Acanthogonyleptes fulvigranulatus $(3,08 \%)$ and Discocyrtus invalidus (4,17\%), while Liogonyleptoides sp. 1 was dominant $(6,17 \%)$. The eudominant species
Discocyrtanus pertenuis $(15,02 \%)$ and Mischonyx cuspidatus $(55,84 \%)$ (Table 4$)$ should be highlighted here.

TABLE 4: Abundance, frequency, constancy and dominance of the Opiliones species sampled in different fragments of a Seasonal Semidecidual Forest in municipalities in the south of the state of Minas Gerais, Brazil.

\begin{tabular}{lcccc}
\hline \multicolumn{1}{c}{ Species } & No. of indv. & \% freq. & Constancy & Dominance \\
\hline Acanthogonyleptes fulvigranulatus & 37 & 3.088481 & Accidental & Subdominant \\
Acanthogonyleptes sp. 1 & 3 & 0.250417 & Accidental & Rare \\
Acutisoma longipes & 20 & 1.669 .449 & Accidental & Recessive \\
Anoplogynus sp. 1 & 2 & 0.166945 & Accidental & Rare \\
Anoplogynus sp. 2 & 2 & 0.166945 & Accidental & Rare \\
Anoplogynus nasutus & 3 & 0.250417 & Accidental & Rare \\
Asarcus sp. 1 & 1 & 0.083472 & Accidental & Rare \\
Currala sp. 1 & 8 & 0.66778 & Accidental & Rare \\
Discocyrtus bos & 9 & 0.751252 & Accidental & Rare \\
Discocyrtus confusus & 13 & 1.085142 & Accidental & Recessive \\
Discocyrtus invalidus & 50 & 4.173623 & Accidental & Subdominant \\
Discocyrtus flavigranulatus & 2 & 0.166945 & Accidental & Rare \\
Discocyrtanus pertenuis & 180 & 1.502504 & Accidental & Eudominant \\
Discocyrtus sp. 1 & 4 & 0.33389 & Accidental & Rare \\
Discocyrtus latus & 4 & 0.33389 & Accidental & Rare \\
Discocyrtoides nigricans & 2 & 0.166945 & Accidental & Rare \\
Encheiridium montanum & 3 & 0.250417 & Accidental & Rare \\
Gagrellinae sp.1 & 04 & 0.33389 & Acidental & Rara \\
Gagrellinae sp. 2 & 14 & 1.168614 & Acidental & Recessiva \\
Gagrellinae sp. 3 & 1 & 0.083472 & Accidental & Rare \\
Gagrellinae sp.4 & 1 & 0.083472 & Accidental & Rare
\end{tabular}




\begin{tabular}{lcccc} 
Gonyleptidae sp.1 & 10 & 0.834725 & Accidental & Rare \\
Gryne sp.1 & 3 & 0.250417 & Accidental & Rare \\
Goniosomatinae sp.1 & 6 & 0.500835 & Accidental & Rare \\
Gonyleptes atrus & 12 & 1.001669 & Accidental & Recessive \\
Gonyleptes sp.1 & 10 & 0.834725 & Accidental & Rare \\
Hypophyllonomus sp.1 & 3 & 0.250417 & Accidental & Rare \\
Liogonyleptoides sp.1 & 74 & 6.176962 & Accidental & Dominant \\
Longiperna sp.1 & 23 & 1.919 .866 & Accidental & Recessive \\
Longiperna trembao & 2 & 0.166945 & Accidental & Rare \\
Mischonyx cuspidatus & 669 & 5.584307 & Constant & Eudominant \\
Mitobatinae sp.1 & 1 & 0.083472 & Accidental & Rare \\
Pachylinae sp.1 & 21 & 1.752922 & Accidental & Recessive \\
Tricommatinae sp.1 & 1 & 0.083472 & Accidental & Rare \\
\hline
\end{tabular}

\section{Discussion}

The abundance of Opiliones in this study was superior to that of other surveys carried out in a Seasonal Semidecidual Forest in Minas Gerais (SOARES, 1970), in São Paulo (PINTO-DA-ROCHA et al., 2005; RESENDE et al., 2012), in Paraná and in Santa Catarina (PINTO-DA-ROCHA et al., 2005). This may be due to the fact that a larger area was sampled and to a greater sampling effort. The high abundance in Atlantic Rainforest areas is a reflection of different factors, as discussed by Nogueira et al. (2019b), who reports the occurrence of 508 species in 63 locales along the Brazilian coast in 11 states and three regions.

Contrary to most other tropical harvestmen species, which are endemic to certain geographical regions (PINTO-DA-ROCHA et al., 2005), Mischonyx cuspidatus has the largest dispersion territory among Brazilian species (KURY, 2003), besides being easily found in urban areas (MESTRE; PINTO-DA-ROCHA, 2004), demonstrating that it is a generalist species, i.e., has little specificity and a great capacity of dispersion.

Regarding the unheard-of species to science, the Anoplogynus sp.1 and sp.2 belong to the subfamily Pachylinae, which has 129 known genera and 400 known species. The genus Anoplogynus, so far, had a species known in Brazil, Anoplogynus nasutus Piza, 1938, found in São Paulo (KURY, 2003). Liogonyleptoides sp. 1 belongs to the subfamily Gonyleptinae that encompasses 142 species distributed in 38 genera, among which are Liogonyleptoides, with five species known in the Atlantic Rainforest biome so far. Liogonyleptoides capichaba Soares \& Soares, 1946, occurs in Espírito Santo; Liogonyleptoides minensis (Piza, 1946) and Liogonyleptoides heliae Kury, 2003, in Minas Gerais; Liogonyleptoides tetracanthus (MelloLeitão, 1932) in Rio de Janeiro; and Liogonyleptoides inermis (Mello-Leitão, 1922) in Minas Gerais, Rio de Janeiro, Santa Catarina and São Paulo (KURY, 2003); the Tricommatinae sp.1 morphospecies belongs to this subfamily, that is comprised of six species and three genera, and can be easily found in the Atlantic Rainforest in eastern Brazil (KURY, 2014).

The species estimator reports a high efficiency in sample collection, around $81 \%$. However, a larger number of sample collections would allow the cataloging of more species.

The similarity of the present survey is indicated to be greater (0.21052) to the Ferreira et al. (2019) survey than others. Nevertheless, this value is low - values are only considered meaningful over 0.5 (KENT; COKER, 1992). This situation was observed in all the other studies (Table 3), which might be due to the endemism of the order, as discussed by other authors (PINTO-DA-ROCHA et al., 2005; FERREIRA et al., 2019). This justifies more catalog studies for this taxon in conservation units in those areas considered as 
potential for invertebrates in the state of Minas Gerais (DRUMMOND et al., 2005), in order to know the species and biodiversity distribution better.

The abundance of the species Mischonyx cuspidatus and Discocyrtanus pertenuis can be explained by two factors. First, for being considered a synanthropic species of wide geographic distribution, tolerating environments impacted by human activity (BRAGAGNOLO et al., 2007; ÁZARA et al., 2018), as is characteristic of many areas sampled in this study.

The second factor is their gregarious behavior, observed, so far, in Eupnoi and Laniatores (MACHADO; MACÍAS-ORDÓÑEZ, 2007). This enabled the capture of a larger number of individuals of the species during the sampling, which impacted the registered abundance. Among the hypotheses that have been proposed for the gregarious formation in some species in this order are the protection against predators, hydro regulation, and the increase in successful mating (MACHADO; MACÍASORDÓÑEZ, 2007). The gregarious individuals usually rest in moist places, under tree trunks, caves, or plants (CURTIS; MACHADO, 2007; MACHADO; MACÍASORDÓÑEZ, 2007; CHELINI et al., 2011) and there is evidence of philopatry in several species: at night, the gregarious individuals go out to forage and return to their resting place at dawn (GNASPINI, 1996; MACHADO et al., 2000; WILLEMART; GNASPINI, 2004; DONALDSON; GRETHER, 2007; GRETHER; DONALDSON, 2007).

It should be pointed out that the distribution of the Mischonyx species is restricted to the center/south of Brazil and spans the states of Goiás (Distrito Federal), Minas Gerais, Espírito Santo, Rio de Janeiro, São Paulo, Paraná, Santa Catarina and Rio Grande do Sul. Most species allocated in the genus Mischonyx have high endemism and wide allopatry (VASCONCELOS, 2003). On the other hand, Discocyrtanus pertenuis presents distribution throughout the Central region (Brazilian savanna) and east (Atlantic Rainforest in Minas Gerais and São Paulo) of Brazil (KURY; CARVALHO, 2016). Therefore, the eudominance of these species in this study and their endemic nature in the phytophysiognomy collection is justified.
The places where the new species were registered (Municipality: Bueno Brandão, Albertina, and Inconfidentes) are not found in conservation units or protected areas, which poses a threat to the maintenance of the species unknown until now, i.e., Tricommatinae sp.1, Anoplogynus sp.1, sp.2 and Liogonyleptoides sp.1. Therefore, this research recommends carrying out long-term studies on the biology and distribution of the species, in order to identify its vulnerability.

The diverstity of opiliones may vary due to different factors, such as precipitation, temperature, altitude, and humidity, but also due to biogeographic aspects (ALMEIDA-NETO et al., 2006; NOGUEIRA et al., 2019b; FERREIRA et al., 2020), which added to the endemism rates (PINTO-DA-ROCHA et al., 2005) must be considered in order to define the conservation strategies of these animals.

Considering the results presented, the studied area is relevant to the Opiliones fauna in the state of Minas Gerais, which added to the diversity studies of other taxons in the region (PASSARI et al., 2017; AMORIM, et al., 2018; BUENO et al., 2019; VIEIRA et al., 2020), justifies the creation of Conservation Units in order to ensure the protection of this natural heritage, since none of the studied areas are included in environmental protection areas.

\section{Acknowledgements}

To Dr. Ricardo Pinto da Rocha (USP) for aiding in the identification of the biological material; to the Instituto Federal de Educação, Ciência e Tecnologia do Sul de Minas Gerais, Câmpus Inconfidentes for the logistics; and to the interns at the Zoology Laboratory of Instituto Federal de Educação, Ciência e Tecnologia do Sul de Minas Gerais, Câmpus Inconfidentes for their assistance in the field.

\section{References}

ALENCAR, A. A. C.; SOLÓRZANO, L. A.; NEPSTAD, D. C. Modeling forest understory fires in an eastern Amazonian landscape. Ecological Applications, Washington, v. 14, n. 4, p. 139-149, 2004. 
ALMEIDA-NETO, M.; MACHADO, G.; PINTO-DA-ROCHA, R.; GIARETTA, A. Harvestman (Arachnida: Opiliones) species distribution along three Neotropical elevational gradients: an alternative rescue effect to explain Rapoport's rule? Journal of Biogeography, New York, v. 33, n. 2, p. 361-375, 2006.

AMORIM, M. S.; SOUZA, M. M.; DOS ANJOS, C. S. Riqueza de libélulas (Insecta: Odonata) no município de Bueno Brandão, sul de Minas Gerais. MG.Biota, Belo Horizonte, v. 11, n. 1, p. 16-32, 2018.

ÁZARA, L. N.; BERNARDI, L. F. O.; FERREIRA, R. L. The first survey on harvestmen in Brazilian artificial cavities, with notes on distribution and natural history. Subterranean Biology, Sofia, v. 17, p. 31-53, 2016.

ÁZARA, L. N.; FERREIRA, R. L. Annotated checklist of Gonyleptoidea (Opiliones: Laniatores) associated with Brazilian caves. Zootaxa, Auckland, v. 4439, n. 1, p. 1-107, 2018.

BRAGAGNOLO, C.; NOGUEIRA, A. A.; PINTO-DA-ROCHA, R.; PARDINI, R. Harvestmen in an Atlantic forest fragmented landscape: Evaluating assemblage response to habitat quality and quantity. Biological Conservation, Boston, v. 139, n. 3-4, p. 389400, 2007.

BRAGAGNOLO, C.; PINTO-DA-ROCHA, R. Diversidade de opiliões do Parque Nacional da Serra dos Órgãos, Rio de Janeiro, Brasil (Arachnida: Opiliones). Biota Neotropica, Campinas, v. 3, n. 1, p. 1-24, 2003.

BRAGAGNOLO, C.; PINTO-DA-ROCHA, R. Os opiliões. In: LOPES, M. I. M. S.; KIRIZAWA, M.; MELO, M. M. R. F. (Ed.). Patrimônio da Reserva Biológica do Alto da Serra de Paranapiacaba. A antiga Estação Biológica do Alto da Serra. São Paulo: Instituto de Botânica, 2009. p. 525-536.

BUENO, E. T.; SOUZA, M. M.; CLEMENTE, M. A. The effect of forest fragmentation on Polistinae. Sociobiology, Feira de Santana, v. 66, n. 3, p. 508-514, 2019.

CHELINI, M. C.; WILLEMART, R. H.; GNASPINI, P. Caves as a winter refuge by a neotropical harvestman (Arachnida, Opiliones). Journal of Insect Behavior, New York, v. 24, n. 5, p. 393-398, 2011.

CURTIS, D. J.; MACHADO, G. Ecology. In: PINTO-DA-ROCHA, R.; MACHADO, G.; GIRIBET, G. (Ed.). Harvestmen: the biology of Opiliones. Cambridge: Harvard University Press, 2007. p. 280308.

DASILVA, M. B.; PINTO-DA-ROCHA, R.; SOUZA, A. M. A protocol for the delimitation of areas of endemism and the historical regionalization of the Brazilian Atlantic Rain Forest using harvestmen distribution data. Cladistics, New York, v. 31, n. 6, p. 1-28, 2015.

DONALDSON, Z. R.; GRETHER, G. F. Tradition without social learning: scent-mark-based communal roost formation in a neotropical harvestman (Prionostemma sp.). Behavioral Ecology and Sociobiology, Göttingen, v. 61, n. 5, p. 801-809, 2007.

DRUMMOND, G. M.; MARTINS C. S.; MACHADO, A. B. M.; SEBAIO, F. A.; ANTONINI, Y. Biodiversidade em Minas Gerais: um atlas para a sua conservação. Belo Horizonte: Fundação Biodiversitas, 2005. 208 p.

FERREIRA, A. S.; PINHEIRO, I. L. C.; ÁZARA, L. N.; CLEMENTE, M. A.; SOUZA, M. M. Biodiversidade de Opiliones
(Arachnida) em áreas de Cerrado e Mata Atlântica no Brasil. Nature and Conservation, Aracaju, v. 13, n. 2, p. 38-46, 2020.

FERREIRA, A. S.; PINHEIRO, I. L. C.; SOUZA, M. M. Opiliones (Arachnida) in a mixed forest in Southern Minas Gerais state, Brazil. Journal of Entomology and Zoology Studies, Delhi, v. 7, n. 5 , p. 666-671, 2019

FRIEBE, B. Zur biologieeines buchenwaldbodens: 3. Die kaferfauna. Carolinea, Karlshue, v. 41, p. 45-80, 1983.

GNASPINI, P. Population ecology of Goniosoma spelaeum, a cavernicolous harvestman from south-eastern Brazil (Arachnida: Opiliones: Gonyleptidae). Journal of Zoology, London, v. 239, n. 3, p. 417-435, 1996.

GRETHER, G. F.; DONALDSON, Z. R. Communal roost site selection in a neotropical harvestman: habitat limitation vs. tradition. Ethology, Weinheim, v. 113, n. 3, p. 290-300, 2007.

HAMMER, Ø.; HARPER, D. A. T.; RYAN, P. D. PAST: Paleontological Statistics Software package for education and data analysis. Palaeontologia Electronica, Oslo, v. 4, n. 1, p. 1-9, 2001.

KENT, M.; COKER, P. Vegetation description and analysis. London: Belhaven Press, 1992. 363 p.

KURY, A. B. Checklist of valid genera of Opiliones of the World. Rio de Janeiro: Museu Nacional/UFRJ website. 2002 [and onward]. Disponível em: <http://www.museunacional.ufrj.br/mndi/ Aracnologia/checklaniator.htm/>.

KURY, A. B. Annotated catalogue of the Laniatores of the New World (Arachnida, Opiliones). Revista Ibérica de Aracnología, Zaragoza, v. especial monográfico 1, p. 1-337, 2003.

KURY, A. B. Why does the Tricommatinae position bounce so much within Laniatores? A cladistic analysis, with description of a new family of Gonyleptoidea (Opiliones, Laniatores). Zoological Journal of the Linnean Society, London, v. 172, n. 1, p. 1-48, 2014.

KURY, A. B. Classificação dos Opiliones. Site do Museu Nacional/ UFRJ. 2017. Disponível em: <http: www.museunacional.ufrj.br/ mndi/Aracnologia/opiliones.html>.

KURY, A. B.; CARVALHO, R. N. Revalidation of the Brazilian genus Discocyrtanus, with description of two new species (Opiliones: Gonyleptidae: Pachylinae). Zootaxa, Auckland, v. 4111, n. 2, p. 126-144, 2016.

LAMBIN, E. F.; GEIST, H. J.; LEPERS, E. Dynamics of landuse and land-cover change in tropical regions. Annual Review of Environment and Resources, Palo Alto, v. 28, n. 1, p. 205-241, 2003.

LAURANCE, W. F. Forest-climate interactions in fragmented tropical landscapes. Philosophical Transactions of the Royal Society of London, Series B, Biological Sciences, London, v. 359, n. 1443 , p. 345-352, 2004.

LAURANCE, W. F.; COCHRANE, M. A. Synergistic effects in fragmented landscapes. Conservation Biology, Hoboken, v. 15, n. 6, p. 1488-1489, 2001.

MACHADO, G.; MACÍAS-ORDÓÑEZ, R. Social behavior. In: PINTO-DA-ROCHA, R.; MACHADO, G.; GIRIBET, G. (Ed.). Harvestmen: the biology of Opiliones. Cambridge: Harvard University Press, 2007. p. 400-413.

MACHADO, G.; PINTO-DA-ROCHA, R.; GIRIBET, G. What 
are harvestmen? In: PINTO-DA-ROCHA, R.; MACHADO, G.; GIRIBET, G. (Ed.). Harvestmen: the biology of Opiliones. Cambridge: Harvard University Press, 2007. p. 1-13.

MACHADO, G.; RAIMUNDO, R. L. G.; OLIVEIRA, P. S. Daily activity schedule, gregariousness, and defensive behaviour in the neotropical harvestman Goniosoma longipes (Opiliones: Gonyleptidae). Journal of Natural History, London, v. 34, n. 4, p. 587-596, 2000.

MATHIEU, J.; ROSSI, J. P.; MORA, P.; LAVELlE, P.; MARTINS, P. F. D.; ROULAND, C.; GRIMALDI, M. Recovery of soil macrofauna communities after forest clearance in Eastern Amazonia, Brazil. Conservation Biology, Hoboken, v. 19, n. 2, p. 1598-1605, 2005.

MESTRE, L. A. M.; PINTO-DA-ROCHA, R. Populations dynamics of an isolated population of harvestmen Ilhaia cuspidata (Opiliones, Gonyleptidae) in Araucaria Forest (Curitiba, Paraná, Brazil). The Journal of Arachnology, Chicago, v. 32, p. 208-220, 2004.

MOORE, J. C.; HUNT, H. W.; ELLIOTT, E. T. Ecosystem perspectives, soil organisms and herbivores. In: BARBOSA, P.; KRISCHIK, V. A.; JONES, C. G. (Ed.). Microbial mediation of plant-herbivore interactions. New York: John Wiley \& Sons, Inc., 1991. p. 105-140.

NOGUEIRA, A. A.; BRAGAGNOLO, C.; SILVA, M. B.; CARVALHO, L. S.; BENEDETTI, A. R.; PINTO-DA-ROCHA, R. Spatial variation in phylogenetic diversity of communities of Atlantic Forest harvestmen (Opiliones, Arachnida). Insect Conservation and Diversity, Hoboken, v. 12, n. 5, p. 414-426, 2019a.

NOGUEIRA, A. A.; BRAGAGNOLO, C.; SILVA, M. B.; MARTINS, T. K.; LOORENZO, E. P.; PERBICHE-NEVES, G.; PINTO-DA-ROCHA, R. Historical signatures in the alpha and beta diversity patterns of Atlantic Forest harvestman communities (Opiliones-Arachnida). Canadian Journal of Zoology, Otawa, v. 97, n. 7, p. 631-643, 2019b.

OLIVEIRA-FILHO, A. T. Definição e delimitação de domínios e subdomínios das paisagens naturais do estado de Minas Gerais. In: SCOLFORO, J. R.; CARVALHO, L. M. T. (Ed.). Mapeamento e inventário da flora e dos reflorestamentos de Minas Gerais. Lavras: Universidade Federal de Lavras, 2006. p. 21-35.

PASSARI, G. J.; SOUZA, M. M.; MANHAES, M. Composição da avifauna do IFSULDEMINAS - Campus Inconfidentes. Revista Agrogeoambiental, Pouso Alegre, v. 9, n. 2, p. 11-25, 2017.

PINTO-DA-ROCHA, R. Opiliones. In: BRANDÃO, C. F. F.; CANCELLO, E. M. (Ed.). Invertebrados terrestres. São Paulo: FAPESP, 1999. p. 35-44.
PINTO-DA-ROCHA, R.; DASILVA, M. B.; BRAGAGNOLO, C. Faunistic similarity and historical biogeography of the harvestmen of southern and southeastern Atlantic Rain Forest of Brazil. The Journal of Arachnology, Chicago, v. 33, n. 2, p. 290-299, 2005.

R DEVELOPMENT CORE TEAM. R: a language and environment for statistical computing. Vienna: R Foundation for Statistical Computing. 2017. Disponível em: <http://www. R-project.org/>.

REGO, F. N. A. A.; VENTICINQUE, E. M.; BRESCOVIT, A. D. Effects of forest fragmentation on four Ctenus (AraneaeCtenidae) spider population in central Amazonia, Brazil. Studies on Neotropical Fauna and Environment, London, v. 42, n. 2, p. $137-144,2007$.

RESENDE, L. P. A.; PINTO-DA-ROCHA, R.; BRAGAGNOLO, C. The harvestmen fauna (Arachnida: Opiliones) of the Parque Estadual Carlos Botelho, and the Floresta Nacional de Ipanema, São Paulo, Brazil. Biota Neotropica, Campinas, v. 12, n. 4, p. 146$155,2012$.

SANTOS, F. H. Ecology. In: PINTO-DA-ROCHA, R.; MACHADO, G.; GIRIBET, G. (Ed.). Harvestmen: the biology of Opiliones. Cambridge: Harvard University Press, 2007. p. 473-488.

SHEPHERD, G. J. Fitopac 2.1. Campinas: Universidade Estadual de Campinas, 2010.

SILVEIRA NETO, S.; NAKANO, O.; BARBIN, D.; NOVA, N. A. V. Manual de ecologia de insetos. São Paulo: Agronômica Ceres, 1976. 419 p.

SOARES, A. M.; SOARES H. E. M. Opiliones de Itatiaia (Opiliones: Gonyleptidae, Phalangodidae). Revista Brasileira de Biologia, São Carlos, v. 30, n. 3, p. 339-350, 1970.

SOARES, H. E. M. Gonyleptidae from Poços de Caldas, state of Minas Gerais, Brazil (Opiliones, Gonyleptidae). Revista Brasileira de Biologia, São Carlos, v. 30, n. 2, p. 211-216, 1970.

VASCONCELOS, E. G. Revisão taxonômica de Mischonyx Bertkau, 1880 (Opiliones: Laniatores: Gonyleptidae). 2003. 97 f. Dissertação (Mestrado em Zoologia) - Universidade Federal do Rio de Janeiro, Rio de Janeiro. 2003.

VIEIRA, L. R.; SILVA, L. D.; OLIVEIRA, L. A.; ROSA, A. H. B.; SOUZA, M. M. Borboletas (Lepidoptera, Papilionoidea) em floresta estacional semidecidual do sul do estado de Minas Gerais, Brasil. Nature and Conservation, Aracaju, v. 13, n. 2, p. 14-25, 2020.

WILLEMART, R. H.; GNASPINI, P. Spatial distribution, mobility, gregariousness, and defensive behaviour in a Brazilian cave harvestman Goniosoma albiscriptum (Arachnida, Opiliones, Gonyleptidae). Animal Biology, Palermo, v. 54, n. 3, p. 221-235, 2004.

ZHANG, Z. Q. Phylum Arthropoda. Zootaxa, Auckland, v. 3703, n. 1, p. 17-26, 2013. 